\title{
Pharmaceuticals from natural products: current trends*
}

\author{
PETER R. SEIDL \\ Escola de Química da Universidade Federal do Rio de Janeiro (UFRJ), Centro de Tecnologia, Bloco E \\ 21949-900 Rio de Janeiro, RJ, Brazil \\ Manuscript received on September 24, 2001; accepted for publication on October 8, 2001; \\ presented by AFFONSO GUIDÃo GoMES
}

\begin{abstract}
The use of products extracted from plants for medicinal purposes can be traced to the beginnings of civilization and up until the end of the nineteenth century natural products were the principal source of medicines. Since then their relative importance has oscillated according to the strategies of large pharmaceutical companies. Now that these strategies are changing, there are new opportunities for countries like Brazil, in which a large proportion of the world's biodiversity is located. There are, however, new circumstances that must be taken into consideration: material must be collected by groups which are formally authorized to do so and under the conditions of the Convention of Biological Diversity, the discovery process is being successively outsourced to smaller specialized firms and there is a growing integration with producers of cosmetics and phytomedicines.
\end{abstract}

Key words: pharmaceutical industry, outsourcing, collection, benefit-sharing, integration.

\section{INTRODUCTION}

The use of products extracted from plants for medical purposes can be traced to the beginnings of civilization. In fact, early work on cultivation and classification of plants has much to do with their use in the treatment of many different types of human ailments and up until the identification of active principles and their synthesis on an industrial scale at the end of the nineteenth century, natural products were the principal source of medicines. Since then, their share of the pharmaceutical market declined significantly and nowadays their relative importance has oscillated according to the discoveries coming out of research laboratories and the strategies of large pharmaceutical companies.

Correspondence to: Peter Rudolf Seidl

E-mail: pseidl@eq.ufrj.br

*Presented at XXII RESEM (2000).
The momentum for change in the pharmaceutical industry and the opportunities it provides for integrating compounds isolated from natural products into the discovery process have already been pointed out (Seidl 1999). The heart of the problem faced by this industry and the momentum for the change it is going through is the risk associated with the discovery of new products. A small fraction of the products that are tested reach the clinical phases and very few of these compounds will ever been registered and marketed. Thus there is a large degree of uncertainty associated with the rising costs that are required to bring a new compound to market (Cavalla 1998).

In an effort to decrease research times, new technologies have been introduced into the process of innovation in the pharmaceutical industry. This had led to increased enterpreneurial activity in the 
biotechnology sector which, along with the mergers and acquisitions with concomitant downsizing that are occurring among the large pharmaceutical companies (Cavalla 1998) provides an opportunity for new players to enter the field. Countries like Brazil, in which a large proportion of the world's biodiversity is found, tent to benefit from this situation. Two of the world's largest pharmaceutical companies already have shown their interest in working with Brazilian natural products through formal arrangements and local companies are beginning to invest significantly in the area. There are, however, new circumstances that must be considered in the investigation of active principles from Brazilian natural products: accepted practices and legislation under discussion require collection by legally authorized groups working under conditions established by the Convention on Biological Diversity, activities related to discovery of active principles are being outsourced to small specialized firms and there is a growing interface between pharmaceutical companies and those which deal with phytomedicines, nutritional additives and cosmetics. These trends may provide new opportunities and constraints for the investigation of active principles in Brazilian natural products.

\section{NATURAL PRODUCTS IN THE PHARMACEUTICAL INDUSTRY}

Natural products have traditionally been an important source of pharmaceuticals. Although synthetic chemistry has also produced many new bioactive substances and combinatorial techniques have considerably expanded the number of compounds available for tests, there are still a relatively high number of natural products and their derivatives among the best selling drugs and there has been a renewed interest in natural products as a source of pharmaceuticals (Seidl 1999). It has been recently shown (Zurer 1999) that the types of natural products that evidence biological activity are quite different from their synthetic counterparts and statistical evaluations show a clear difference between the structural properties of natural products and synthetic compounds. As the degree of differences between natural products of different sources is also very high and there many sources of natural products are relatively untapped, interest in developing active principles from biodiversity will probably continue for a long time.

Drawbacks in the use of natural products in large-scale screening projects derive from the uncertainties in obtaining sufficient amounts of material, the variability in composition of samples and in tracing some form of activity to certain structures contained in extracts (Seidl 1999). It would appear that these uncertainties, associated with the risks that are inherent to new product introduction in the pharmaceutical industry, should make isolation of active principles from natural product quite unattractive. However, the efforts to shorten research times have increased the degree of specialization required for research, discovery and development of candidates for exploratory development and provide powerful incentive for outsourcing development programs (Cavalla 1998). Whereas until recently nearly all pharmaceutical research was conducted internally, modern strategy now endorses research portfolios that include projects or technology partly provided extramurally by biotechnology companies and academic groups. Many of the uncertainties in collection, identification and screening are significantly reduced when these activities are coordinated by specialized companies or academic groups. Two of the world's largest pharmaceutical companies have negotiated agreements that would provide an access to compounds isolated from Brazilian natural products though arrangements of this type.

The introduction of new chemical entities (NCEs) for human therapeutical use may be indicative of trends and perspectives in the pharmaceutical industry. Data on the last five years, collected from Annual Reports in Medicinal Chemistry (Table I), is very illustrative. An increasing number of NCEs originate in firms that are not among the major pharmaceutical companies, some of them in countries that are new to the area. In the last two years, a rather large number of new biological enti- 
ties (NBEs) were launched along with the NCEs. In 1998 there was roughly one NBE for 3 NCEs (Galatsis 1998) and in 1999 this proportion remained significant. It is also noteworthy that other biological entities, not considered NBEs, obtained from natural products were also launched in 1999 and that Arglabin, a new antineoplastic agent with promising response to "difficult-to-treat" cancers can be obtained by extraction from a plant from Kazakstan (Berna and Gaudillière 2000).

\section{PHYTOMEDICINES AND COSMETICS}

In spite of the large market for pharmaceutical products in Brazil, none of the major companies is owned locally. Thus the research on compounds which may have biological activity is almost exclusively limited to academic institutions, government laboratories or small to medium-size firms that produce phytomedicines.

This situation may be changing. The market for phytomedicines is estimated at US\$400 million a year and grows at a $12 \%$ rate (Rios 2000). The rapid development of a more sophisticated market for herbal remedies and nutritional supplements has led to growing pressure for regulation and testing. Many small projects involving services provided by academic groups to producers of phytomedicines have developed from quality control into more ambitious investigations of chemical composition and active constituents of existing products.

This situation has caught the attention of larger companies in the area of cosmetics. Contrary to the pharmaceutical industry, two out of the three largest producers of cosmetics in the country are Brazilianowned. They already have strong ties with sources of natural products that provide many of the raw materials that are used in their formulations. They also have an appreciation and have made strong public commitments to conservation of natural resources and promotion of sustainable development practices.

All three of the largest cosmetics firms are moving into the health area (Rios 2000). The second largest company has just bought a traditional producer of phytomedicines and the third is discussing partnerships for distribution through its franchising network. They are very optimistic about the near future, as they probably should be, since relationship between health and nutrients is being put on a very sound basis (Ottaway 2001).

\section{SOCIAL BENEFITS OR BUSINESS OPPORTUNITIES}

There are, however, important questions that must be addressed. The high stakes involved in the protection and exploitation of biological wealth led to the conclusion of the Convention on Biological Diversity that puts an end to the "commons" status of biological resources. This material within a country's borders is now defined as a national patrimony but, although the convention has partially solved some of the political problems at an international level, there are still internal conflicts that may complicate formal access (Wijk 2000). Intentionally, this question is being addressed through International Cooperative Biodiversity Groups (ICBG). Launched in 1993 by the National Institutes of Health, the National Science Foundation and the US Agency for International Development, they have set up arrangements in several countries (Table II) which provide short and long-term compensation for the local partners that are involved (Rouhi 1997). In Brazil, questions of access to natural resources have been under discussion in Congress for over five years now and have taken on distinct political connotations. These correspond to an additional level of complexity for questions concerning territorial and ethnic rights and socio-economic conditions of local populations. Subjacent to these discussions are the rights to the materials that are collected in a certain placeone of the bills under consideration extends the patrimony concept to the local community. This is no small question as is evident from the policy statement of the world's largest pharmaceutical company:

Glaxo Wellcome plc is aware of, and sensitive to, issues relating to biodiversity and conservation. In 
TABLE I

New Chemical Entities (NCEs) by country of origin, 1995-1999.

\begin{tabular}{l|c|c|c|c|c}
\hline & $1995^{\mathrm{a}}$ & $1996^{\mathrm{b}}$ & $1997^{\mathrm{c}}$ & $1998^{\mathrm{d}}$ & $1999^{\mathrm{e}}$ \\
\hline US & $8^{\mathrm{f}}$ & 10 & 10 & 13 & 14 \\
Japan & 10 & 4 & 7 & 3 & 7 \\
UK & 5 & 8 & 6 & 1 & 3 \\
Germany & 1 & 5 & 4 & 5 & 4 \\
Switzerland & 4 & 4 & 3 & 2 & - \\
France & 3 & 1 & 3 & 2 & 1 \\
Sweden & $1^{\mathrm{f}}$ & 1 & 1 & - & - \\
India & 1 & - & - & - & - \\
Spain & 1 & - & 1 & - & - \\
Canada & 1 & - & - & - & - \\
Netherlands & 1 & 1 & - & - & 2 \\
Denmark & - & 3 & - & - & - \\
Australia & - & 1 & - & - & - \\
Italy & - & - & 2 & - & - \\
Israel & - & - & 2 & - & - \\
Norway & - & - & 1 & - & - \\
Finland & - & - & - & 1 & - \\
Kazakstan & - & - & - & - & 1 \\
S. Korea & - & - & - & - & 2 \\
\hline Total & 26 & 38 & 39 & 27 & $36^{\mathrm{g}}$ \\
\hline
\end{tabular}

${ }^{a}$ compiled from Cheng 1996; ${ }^{b}$ compiled from Galatsis 1997; ${ }^{c}$ compiled from Galatsis 1998; d compiled from Gaudillière 1999; ${ }^{\mathrm{e}}$ compiled from Berna and Gaudillière 2000; ${ }^{\mathrm{f}}$ one product originated in US/Sweden and ${ }^{{ }^{2}}$ refers to new therapeutic entities, including new biological entities.

particular, Glaxo Wellcome recognises the importance of matters considered at the United Nations Conventions on Biological Diversity. Glaxo Wellcome Research and Development understands the impact that unauthorised and/or unrestrained removal of natural materials from their indigenous habitats can have on the ecology and economy of a country....

In seeking access to natural materials, Glaxo Wellcome's Research and Development policy is to collaborate with organisations that possess the exper- tise and the authority to obtain such materials from whatever source. Agreements will be concluded with prospective sample supplies only when they can provide documentary evidence that they have permission from appropriate government authorities to collect such samples....

Glaxo Wellcome, A Policy Statement, 1 May 1997.

\section{CONCLUSIONS}

Trends in the way research, discovery and development are carried out in the pharmaceutical industry 
TABLE II

International Cooperative Biodiversity Groups ${ }^{\mathrm{a}}$.

\begin{tabular}{|c|c|c|c|c|c|c|c|}
\hline ICGB & \multicolumn{2}{|l|}{ Principal } & \multicolumn{2}{|c|}{ International } & \multicolumn{2}{|l|}{ Local } & Collection \\
\hline Suriname & \multicolumn{2}{|l|}{$\begin{array}{l}\text { D.G.I. Kingston } \\
\text { VPI\&SU } \\
\text { Blacksburg, VA }\end{array}$} & \multicolumn{2}{|c|}{$\begin{array}{l}\text { Conservation } \\
\text { International }\end{array}$} & \multicolumn{2}{|c|}{ Forest people } & $\begin{array}{l}\text { Ethnobotanical: } \\
\text { Shaman-healers } \\
\text { Conserv. } \\
\text { Internat. Random } \\
\text { Misouri Botan. } \\
\text { Gardens }\end{array}$ \\
\hline Peru & \multicolumn{2}{|c|}{$\begin{array}{l}\text { W.H. Lewis } \\
\text { Washington } \\
\text { Univ. St. Louis, MO }\end{array}$} & & & \multicolumn{2}{|c|}{$\begin{array}{l}\text { Aguaruna \& Univ. } \\
\text { S. Marcos, Lima }\end{array}$} & Ethnobotanical \\
\hline Costa Rica & \multicolumn{2}{|l|}{$\begin{array}{l}\text { J. Meinwald } \\
\text { Cornell Univ. } \\
\text { Ithaca, N.Y. }\end{array}$} & \multicolumn{2}{|c|}{$\begin{array}{l}\text { Cornell (T. Eisner, } \\
\text { J. Clardy) } \\
\text { Bristol-Myers } \\
\text { Squibb }\end{array}$} & \multicolumn{2}{|c|}{$\begin{array}{l}\text { INBIO }^{b} \& \text { Guanacaste } \\
\text { Conserv. Area }\end{array}$} & $\begin{array}{l}\text { Random } \\
\text { Collection } \\
\text { of Insects (D.H. } \\
\text { Janzen Univ. of Penn) }\end{array}$ \\
\hline Africa & \multicolumn{2}{|l|}{$\begin{array}{l}\text { B.G. Schuster } \\
\text { Walter Reed } \\
\text { Army Inst. Res. } \\
\text { Washington D.C. }\end{array}$} & \multicolumn{2}{|c|}{$\begin{array}{l}\text { Smithsonian Inst., } \\
\text { Washington D.C. }\end{array}$} & \multicolumn{2}{|c|}{$\begin{array}{l}\text { Univ. of Dschang, } \\
\text { Cameroon \& Bioresources } \\
\text { Dev. \& Cons. Program } \\
\text { Cameroon and Nigeria }\end{array}$} & Traditional healers \\
\hline Latin America & \multicolumn{2}{|l|}{$\begin{array}{l}\text { B.N. Timmerman } \\
\text { Univ. Arizona, } \\
\text { Tucson, AR }\end{array}$} & \multicolumn{2}{|c|}{$\begin{array}{l}\text { G.W.L. Hansen's } \\
\text { Disease Center, Baton } \\
\text { Rouge, LA } \\
\text { Wyeth-Ayers Res. } \\
\text { Lab., Pearl River, NY } \\
\text { \& American Cyanamid, } \\
\text { Princeton, NJ }\end{array}$} & \multicolumn{2}{|c|}{$\begin{array}{l}\text { Inst. Biol. Res., Buenos } \\
\text { Aires; Nat. Univ. } \\
\text { Patagonia; Nat. Center } \\
\text { Patagonia, Chubut; Pontif. } \\
\text { Catholic Univ. of Chile, } \\
\text { Santiago; National Autom. } \\
\text { Univ. Mexico, Mexico } \\
\text { City }\end{array}$} & $\begin{array}{l}\text { Arid and semiarid } \\
\text { plants in } \\
\text { Argentina, Chile } \\
\text { and Mexico }\end{array}$ \\
\hline & ICBG & \multicolumn{2}{|c|}{ Extraction } & \multicolumn{2}{|l|}{ Analysis } & \multicolumn{2}{|l|}{ Specificity } \\
\hline & Suriname & \multicolumn{2}{|c|}{$\begin{array}{l}\text { BGVS } \\
\text { (Surinamese } \\
\text { Pharm. Co.) }\end{array}$} & \multicolumn{2}{|c|}{$\begin{array}{l}\text { Virginia Tech, } \\
\text { Bristol-Myers } \\
\text { Squibb }\end{array}$} & & \\
\hline & Peru & \multicolumn{2}{|c|}{$\begin{array}{l}\text { Peruvian Univ. } \\
\text { Cayetano } \\
\text { Heredia, Lima }\end{array}$} & \multicolumn{2}{|c|}{$\begin{array}{l}\text { Washington Univ. \& } \\
\text { \& Searle R\&D } \\
\text { (Monsanto) \& Peru }\end{array}$} & & \\
\hline & Costa Rica & \multicolumn{2}{|c|}{ INBIO $^{b}$} & \multicolumn{2}{|c|}{$\begin{array}{l}\text { Bristol-Myers } \\
\text { Squibb, Cornell }\end{array}$} & & \\
\hline & Africa & \multicolumn{2}{|c|}{ Walter Reed } & \multicolumn{2}{|c|}{ Walter Reed } & \multicolumn{2}{|c|}{$\begin{array}{l}\text { Parasitic diseases } \\
\text { (malaria, leishmaniasis, } \\
\text { trypanosomiasis) }\end{array}$} \\
\hline & Latin America & & & & & \multicolumn{2}{|c|}{$\begin{array}{l}\text { Drugs, agricultural and } \\
\text { veterinary chemicals }\end{array}$} \\
\hline
\end{tabular}

${ }^{\mathrm{a}}$ compiled from Rouhi 1997; ${ }^{\mathrm{b}}$ Also has agreement with Merck \& Co, Whitehouse Station, N.J. for a limited number of plant, insect, fungal and environmental samples.

have opened new prospects for incorporating Brazilian natural products into programs of an economic nature. Yet, unless the legal aspects of such pro- grams, such as authority for collection and benefitsharing with local communities, can be worked out and their social consequences are clearly understood 
by the general public, access to the country's biodiversity by multinational corporations may generate controversy and will probably hamper efforts at regulation. Thus, although the occasion may ripe for establishing commercial ventures, stakeholders are urged to proceed with caution lest some of the sensitive issues get out of hand.

\section{ACKNOWLEDGMENTS}

The author holds a research fellowship from the CNPq and thanks Profs. O. Gottlieb and R. Borin as well as Mr. P.J. Paret de Sant'Ana for illuminating discussions of some of the complex issues covered here.

\section{RESUMO}

O uso de produtos extraídos de plantas para fins medicinais pode ser tracejado aos inícios da civilização e até o fim do século XIX, os produtos naturais constituíram a principal fonte de medicamentos. Desde então, a importância relativa dos produtos naturais tem oscilado de acordo com as estratégias de grandes companhias farmacêuticas. Agora que estas estratégias vêm mudando, há novas oportunidades para países como o Brasil, no qual está localizada uma vasta proporção da biodiversidade mundial. Há, entretanto, novas circunstâncias que devem ser levadas em consideração: o material deve ser coletado por grupos que estão formalmente autorizados para tal, com a coleta sendo feita sob as condições da Convenção de Diversidade Biológica, o processo de descoberta está sendo sucessivamente terceirizado no sentido de firmas especializadas menores e há uma integração crescente como produtores de cosméticos e fitomedicamentos.

Palavras-chave: indústria farmacêutica, terceirização, coleta, compartilhamento de benefícios, integração.

\section{REFERENCES}

Berna P And Gaudillière B. 2000. To Market, To Market 1999. In: DoherTy AM (ed.), Annual Reports in Medicinal Chemistry, Vol. 35, San Diego: Academic, p. 331-356.

Cavalla D. 1998. Technology Providers and Integrators - A Virtual Architecture for Drug R\&D? In: BRISTOL JA (ed.), Annual Reports in Medicinal Chemistry, Vol. 33, San Diego: Academic, p. 365-374.

Cheng X. 1996. To Market, To Market - 1995. In: BRISTOL JA (ed.), Annual Reports in Medicinal Chemistry, Vol. 31, San Diego: Academic, p. 337-353.

Galatsis P. 1997. To Market, To Market - 1996. In: Bristol JA (ed.), Annual Reports in Medicinal Chemistry, Vol. 32, San Diego: Academic, p. 305326.

Galatsis P. 1998. To Market, To Market - 1998. In: Bristol JA (ed.), Annual Reports in Medicinal Chemistry, Vol. 33, San Diego: Academic, p. 327354.

Gaudillière B. 1999. To Market, To Market - 1998. In: Doherty AM (ed.), Annual Reports in Medicinal Chemistry, Vol. 34, San Diego: Academic, p. $317-$ 338 .

Ottaway PB. 2001. The Roots of a Health Diet? Chem and Ind, Jan 22: 42-44.

Rios C. 2000. Cosmética Investe em Saúde. Gaz Merc, Nov 24: C1,C6.

Rouni AM. 1997. Seeking Drugs in Natural Products. Chem and Eng News, Apr 7: 14-29.

SEIDL PR. 1999. Prospects for Brazilian Natural Products. An Acad Bras Cienc 71: 239-247.

WiJK JV. 2000. Phytobusiness Requires Social Chemistry. Phytochemistry 55: 93-95.

Zurer P. 1999. When It Comes to Diversity, Nature Comes Out Ahead. Chem and Eng News, Mar 29: 28. 